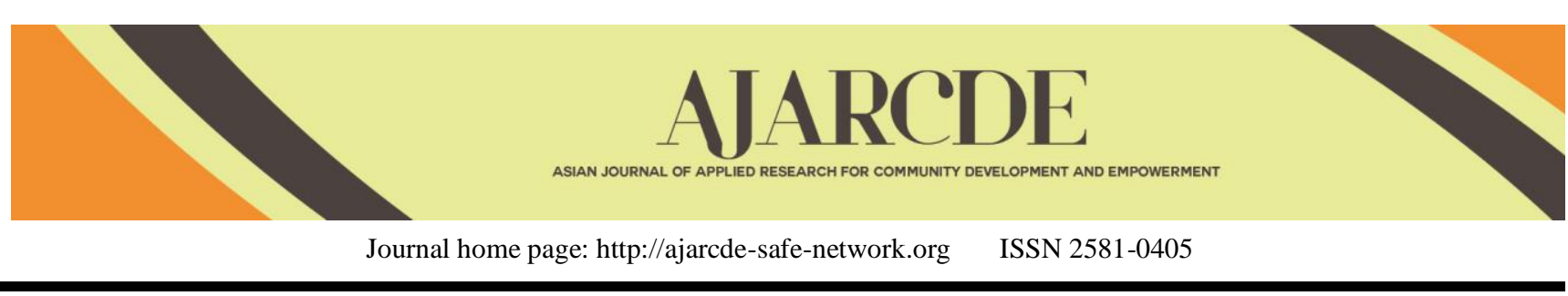

\title{
Potential Analysis of Organic Fertilizer Business Development from Beef Cattle Manure
}

\author{
Muhammad Fikri Hijami ${ }^{1}$, Miftakhul Arifin ${ }^{2}$ and Endah Puspitojati ${ }^{3}$ \\ 1,2,3 Polytechnic of Agricultural Development Yogyakarta-Magelang, Indonesia
}

\section{ARTICLE INFO}

Article History:

Received: 12 October 2021

Final Revision: 21 December 2021

Accepted: 23 December 2021

Online Publication: 05 January 2022

\section{KEYWORDS}

Business Development, Organic Fertilizer, Beef

Cattle Manure

\section{CORRESPONDING AUTHOR}

*E-mail: endahpuspitojati2802@ gmail.com

\begin{abstract}
A B S T R A C T
This study aimed to determine the availability of technical, economic, and social aspects that support the development of organic fertilizer business based on beef cattle manure in Karangtengah Prandon Village, Ngawi District, Ngawi Regency, Indonesia. The research method used interviews, questionnaires, and observation. This study involved 37 respondents who were selected by proportional random sampling technique. The data analysis was carried out by descriptive analysis. The results revealed that the availability of technical aspects has a potential of 64.4 percent, the availability of economic aspects has a potential of 62.7 percent, and the availability of social aspects has a potential of 47.9 percent. The most potential factor of technical aspect was the raw material availability in the location. Meanwhile, social factors, such as labor skills and leader community supports need to be increased. Developing a fertilizer business in Karang Tengah Prandon village may be accomplished by empowering farmers to turn fertilizer into a business.
\end{abstract}

\section{INTRODUCTION}

\subsection{Research Background}

Environmentalism has taken center stage in recent years. The products of organic farming are well-known to be safe for consumption and the environment. Agricultural operations paid more attention to it. In 2021, Indonesia is expected to have a population of 277 million, making it one of the growing and emerging economies. With a population of over 277 million people that is continually rising, organic agricultural goods will undoubtedly find a market in Indonesia in the future [1]. Based on the national survey, there are approximately 15 million people in Indonesia consuming organic foods.

The development of organic agriculture can not be separated from the use of organic fertilizers in their cultivation system. Organic fertilizers significantly contribute to the reduction of dangers connected with mineral fertilizer use. Organic fertilizers supply vital natural carbon for enhancing and maintaining the soil's physical, chemical, and biological qualities during continuous and vigorous agriculture [2].

Cow manure is a type of organic fertilizer; it is a rich source of phosphorus for crops and a decent substitute for commercial phosphorus fertilizer. When manure is used in conjunction with https://doi.org/10.29165/ajarcde.v6i1.80 chemical $\mathrm{P}$ fertilizer, $\mathrm{P}$ availability is increased and crop yields are increased [3].

Adopting organic fertilizer use, on the other hand, is not without drawbacks. The government and other agricultural agencies promote farmers (e.g., the Presbyterian Agricultural Stations-PAS) to apply organic in combination with mineral fertilizers on their land. These agencies have previously assisted smallholder farmers in preparing and applying compost to cereal crops. However, smallholder farmers' traditional organic soil techniques vary considerably, and a lack of options that accommodate their preferences and diverse resource environments is a significant impediment to the technology's adoption. Thus, encouraging farmers to utilize exclusively compost will not result in the desired rate of organic fertilizer use.

Ngawi Regency is located in East Java, Indonesia. The main commodity of this regency is rice with an area of rice fields reaching 38.74 percent of the area [4]. Ngawi Regency possesses the livestock that can be used as potential in the manufacture of manure and compost. The number of cattle in Ngawi Regency in 2019 was 83,431 cows. Ngawi District is one of the areas in Ngawi Regency which has an area of 7,034.50 ha with 50.31 percent or 3539.3 ha in the form of rice fields and 49.68 percent or 3495.2 ha in the form of non-rice fields [4]. The condition of 
the rice fields, which are more than half of the Ngawi District, is supported by the potential of 6,147 cattles.

Karangtengah Prandon Village is one of the villages in Ngawi District with 579.12 ha with an area of 257 ha of rice fields and 322.12 ha of residential land. This village has 8 active farmer groups engaged in rice cultivation. Karangtengah Prandon Village has 875 head of cows, farmers use cow dung waste as organic fertilizer. However, only $65 \%$ of farmers in Karangtengah Prandon Village utilize and process the cow dung into organic fertilizer without special treatment [5].

\subsection{Literature Review}

Cow manure waste is solid waste originating from cattle farming which in the process of disposal is usually mixed with gas and urine. The nutrient content in cow manure varies depending on the production, type, and amount of animal feed consumption. Cow manure is in solid waste such as cow manure, liquid waste such as cow urine, and gaseous waste such as methane gas. Cow dung manure is a composted form of cattle dung with agricultural residue. It improves the soil nutrients, tilth, aeration, and water holding capacity. Cow manure slowly and gradually releases nutrients and stimulates microbial biomass in soils. In India cow dung manure is the most commonly used organic manure, which contains $0.5-0.7 \%$ N, $0.3-0.9 \%$ P205, and $0.4-1.0 \% \mathrm{~K}$, depending upon the type of animals and nature of feed [6].

Cow manure is one source of organic fertilizer. Organic fertilizers are fertilizers that mostly or wholly consist of organic materials derived from plants and or animals that have gone through an engineering process, can be in solid or liquid form which is used to supply organic matter and improve the physical, chemical, and biological properties of the soil. Organic fertilizers are available after the substances and raw materials for making fertilizers undergo a process of decay by micro-organisms in the soil [7].

Cow manure as a source of organic fertilizer can be developed as a business. Fertilizer business development is the task and process of preparing an analysis of potential growth opportunities, supporting and monitoring the implementation of business growth opportunities [8].

In Indonesia, many organic fertilizers industries are unable to survive the business due to their bad performance and even some of them have closed down the business. The decision of closing down the business of the industries in producing organic fertilizer is very tough, as the process of obtaining the production license from the Ministry of Agriculture must go through a long process until the license can be approved [9]. The organic fertilizer business includes fertilizer production activities, fertilizer marketing, as well as training for business groups to be able to run fertilizer business activities in a sustainable manner

\subsection{Research Objective}

This study aimed to determine the availability of technical, economic, and social aspects that support the development of organic fertilizer business from beef cattle dung in Karangtengah Prandon Village, Ngawi Sub-district, Ngawi Regency.

\section{MATERIALS AND METHODS}

The study activity was carried out from November 2020 to April 30, 2021, and the study site was located in Karangtengah Prandon Village, Ngawi District, Ngawi Regency, East Java Province. The study method used in this research is a combination method/mixed method that has a definition, namely a method that uses a combination of qualitative methods and quantitative methods. In this study, qualitative and quantitative methods are used together in a research activity so that the data obtained will be more comprehensive, reliable, objective, and valid.

This study used descriptive data analysis techniques. Descriptive statistics are statistics used to analyze data by describing or describing the data that has been collected as it is without intending to make conclusions that apply to the general public or generalizations. In descriptive statistics, there are data presentations through tables, graphs, pie charts, pictograms, decile calculations, percentile, the calculation of the spread of the data through the calculation of the average and standard deviation, and the calculation of the calculation percentage.

Scores from farmers' answers conducted the process of making data analysis categories and tabulating data. The questionnaire given to farmers is classified into four categories: very potential, potential, less potential, and not potential. Categorization is done by creating an interval class with the width of the interval class determined by the following formula:

$$
I=\frac{R}{K}
$$

Where I, R, and $\mathrm{K}$ were presented as class interval, range ( maximum score- $\Sigma$ minimum score), and number of classes, respectively

Assumption :

$$
\begin{array}{ll}
\text { Maximum value } & : 4(100 \%) \\
\text { Minimum value } & : 1(25 \%) \\
\text { Number of classes } & : 4
\end{array}
$$

\section{RESULT AND DISCUSSION}

Karangtengah Prandon Village consists of 8 hamlets divided into 12 Pillars of Residents and 36 households with an area of 579, 12 ha. They consist of 257 ha of rice fields, 119.49 ha of residential land, and 202.63 ha of dry land.

Table 1. Recapitulation of Potential Development of Organic Fertilizer from Beef Cattle Manure in Karangtengah Prandon

\begin{tabular}{|ccccc|}
\hline \multicolumn{5}{c}{ Village } \\
\hline No & Variable & $\%$ & Criteria & Keterangan \\
\hline 1 & Technical Aspect & 64.4 & $62.6-81.25$ & Potential \\
3 & Economic Aspect & 62.7 & $62.6-81.25$ & Potential \\
3 & Social Aspect & 47.9 & $43.76-62.5$ & Less Potential \\
\hline
\end{tabular}

\subsection{Technical Aspect}

Technical aspects are divided into four potential: raw materials, places, technology, facilities, and infrastructure. The technical aspect produces a percentage of $64.4 \%$ and is included in the potential category. In this study, raw materials are categorized as very potential, technology is categorized as potential, and places and facilities and infrastructure are categorized as less potential. 
Table 2. Technical Aspects Potential of Organic Fertilizer Business Development from Beef Cattle Manure in Karangtengah Prandon Village

\begin{tabular}{|c|c|c|c|}
\hline No & Technical Aspects Potential & Category & $\begin{array}{c}\text { Percentage } \\
(\%)\end{array}$ \\
\hline \multirow[t]{4}{*}{1} & Raw Material & Potential & 81.5 \\
\hline & a. Raw Material Availability & Very Potential & 86.5 \\
\hline & b. The Ease Access to Raw & Potential & 77.7 \\
\hline & c. Raw Material Quality & Potential & 80.4 \\
\hline \multirow[t]{4}{*}{2} & Place & Potential & 63.7 \\
\hline & a. Cow Manure Shelter & Potential & 81 \\
\hline & b. Organic Fertilizer Shelter & Less Potential & 28.3 \\
\hline & c. Cowshed Condition & Potential & 81.7 \\
\hline \multirow[t]{3}{*}{3} & Technology & Less Potential & 56.7 \\
\hline & a. Tools and Materials & Less Potential & 47 \\
\hline & b. Information Access & Potential & 63 \\
\hline \multirow[t]{3}{*}{4} & Facilitiy and Infrastructure & Less Potential & 46.9 \\
\hline & a. Facilities and & Less Potential & 50 \\
\hline & b. Equipment Preparation & Less Potential & 43.9 \\
\hline
\end{tabular}

In general, the potential aspects of raw materials are categorized as very potential. The criteria for the potential aspects of these raw materials are the availability of raw materials, easy access to raw materials, and raw material quality. The criteria for the availability of raw materials in this study were produced by 63 adult cows and 19 calves belonging to 3 farmer groups. Based on data from respondents, 5 out of 37 farmers have used cow dung as raw material for biogas. The utilization of cow dung as biogas requires expensive and more complicated facilities. The farmers who use cow dung as biogas are farmers who receive assistance from Bank BNI. In addition, 32 of the 37 farmers have not used the manure optimally because most of the 32 farmers dispose of cow manure in vain and sell it to fertilizer companies. Only a few farmers use cow manure by storing fertilizer for a few weeks to a year and then applying it to the land without fermentation. This condition causes the criteria for the availability of raw materials to be categorized as very potential with a percentage of $86.5 \%$.

As for the estimation of the availability of the cattle, it produces $13,050 \mathrm{~kg} / \mathrm{month}$ or $156,600 \mathrm{~kg} /$ year. The estimated organic fertilizer from cow manure of $13,050 \mathrm{~kg} / \mathrm{month}$ can meet organic fertilizer needs (PT Petrokimia's recommendation of 500 $\mathrm{kg} / \mathrm{ha}$ ) of 26.1 ha in one month.

On this criterion, most farmers have healthy adult cattle and types of cattle such as Brahman, Limousin, PO, Jawa, and Simetal cattle. One cow can produce $15 \mathrm{~kg}$ /day of manure and if it is processed into organic fertilizer, it will shrink by $40 \%$. There is a potential of 875 head of cattle in Karangtengah Prandon Village with the need for organic fertilizer listed in the Karangtengah Prandon Village RDKK of $188,100 \mathrm{~kg}$ for two planting plans in 1 year [5]. Based on the estimation results of the potential 875 head of cattle can produce $1,916,250 \mathrm{~kg}$ for 1 year, there is a potential of $1,540,050 \mathrm{~kg}$ of organic fertilizer if people who have cattle use their cow manure into organic fertilizer.

Farmers have easy access to cow manure because the cows owned by farmers in the study in these three farmer groups are mostly Brahman cows with more cow manure than ordinary cows. Cows owned by farmers are given good and nutritious feed so that the quality of cow manure owned by farmers is good and healthy.

The potential aspect of the place in this study shows that some farmers already have a shelter to store cow manure and some still do not. This is due to limited land and buildings owned by farmers. Cow manure needs to be stored or protected under the shade so that cow manure's nutrients will not be lost to rainwater and other risks.

This place is divided into three criteria in terms of potential aspects, namely cow manure shelters, organic fertilizer shelters, and cowshed conditions. Cow manure shelters and organic fertilizer shelters are very potential if there is good shade so that they can protect cow manure and organic fertilizers from rain and sunlight. The condition of the cowshed is said to be very potential if it has shade, the floor of the cage has been given a base in the form of cement or carpet, and a minimum distance of 10 meters, and there is a bulkhead between the houses. Potential criteria are the availability of cow manure shelters and the condition of the cowshed. In contrast, the more minor potential criteria are the availability of organic fertilizer shelters, on the criteria that a proper cow manure shelter can cause in the form of improvised shelter, and the condition of the cows that meet the requirements of being less than 10 meters from the house and given a wall barrier. As for the less potential criteria, namely the availability of organic fertilizer production sites because $100 \%$ of the farmers in this study have not started their business activities for organic fertilizer from cow dung. The standard requirement for the availability of a place to accommodate cow manure is ten cows, which is $80 \mathrm{~m}^{2}[10]$.

The potential aspect of technology is divided into two criteria: access to information and tools and materials. Information access criteria are categorized as potential. This is because farmers in this village have received information from agencies that often provide important information in agriculture. The majority of farmers already have access to prices and market information for organic fertilizers. Farmers obtain price and market information through farmer groups, field extension workers, and village officials. The three related elements help each other in the process of delivering this information. However, some farmers still do not have access to prices and the market for organic fertilizers. However, farmers still rarely have the tools and materials to make organic fertilizer because most farmers in Karangtengah Prandon Village have not used cow manure to make organic fertilizer. The materials and equipment needed for the manufacture of organic fertilizers are cow manure mixed with urine, husks/saw wood waste, lime powder, shovels, filters, plastic sacks, scales, and bio stater [11]. The criteria for tools and materials are categorized as less potential because none of the farmers in this study have started an organic fertilizer business. The availability of tools and materials is not sufficient for the organic fertilizer business activity.

Facilities and infrastructure are divided into two criteria, namely facilities and infrastructure availability and equipment Preparation. Both of these criteria are included in the category of less potential. Facilities and infrastructure availability is known that the facilities and infrastructure owned by farmers are not entirely available. Some farmers only have cowsheds and shelters for storing cow manure. In addition, the criteria for equipment preparation obtained the study results in the form of the farmers' equipment not being ready to carry out business activities to 
utilize cow manure into organic fertilizer. This is because the farmers in this study do not have the time and opportunity to take advantage of the potential of cow manure due to the busy activities of farmers in the fields.

\subsection{Economic Aspect}

Table 3. Economic Aspects Potential of Organic Fertilizer Business Development from Beef Cattle Manure in Karangtengah Prandon Village

\begin{tabular}{|c|c|c|c|}
\hline No & Economic Aspects Potential & Category & $\begin{array}{l}\text { Percentage } \\
\quad(\%)\end{array}$ \\
\hline \multirow[t]{3}{*}{1} & Capital & Less Potential & 51.3 \\
\hline & $\begin{array}{l}\text { a. Business Capital } \\
\text { Availability }\end{array}$ & Less Potential & 49.3 \\
\hline & $\begin{array}{l}\text { b. The Ease Access to } \\
\text { Capital }\end{array}$ & Less Potential & 54.7 \\
\hline \multirow[t]{6}{*}{2} & Market & Potential & 67 \\
\hline & a. Market Availability & Potential & 68.9 \\
\hline & $\begin{array}{l}\text { b. Fertilizer Needs Level } \\
\text { Inside the Village }\end{array}$ & Potential & 66.9 \\
\hline & $\begin{array}{l}\text { c. Fertilizer Needs Level } \\
\text { Outside the Village }\end{array}$ & Potential & 67.5 \\
\hline & d. Market Competition & Potential & 76.3 \\
\hline & e. Fertilizer Price & Less Potential & 55.4 \\
\hline
\end{tabular}

In the economic aspect, there are two potential aspects, namely capital, and market. The economic aspect produces a percentage of $62.7 \%$ and is included in the category of potential. In this study of economic aspects, only $0.2 \%$ of the less potential category is in the $43.76 \%-62.5 \%$ interval. The potential aspect of capital is in the category of less potential, while the potential aspect of the market is classified in the category of potential.

In the potential aspect of capital, farmers tend not to have the capital to carry out organic fertilizer business activities. Farmers are also difficult to get capital assistance so that the majority of farmers have not been able to start an organic fertilizer business. The venture capital includes active and passive capital [12]. Active capital in the form of fixed capital includes buildings, equipment, and others to support business activities. Passive capital is a source of capital used in business activities such as money.

Capital is divided into two criteria, namely the business capital availability and the ease to access capital. Based on this study, the two criteria are categorized as less potential. This is because it is difficult to get venture capital to start a new business. For farmers in this study, the terms and conditions of borrowing money are complicated if they do not have guarantees for their administration. In addition, most farmers spend their business capital for their needs in the fields and the tempe processing business.

In the potential aspect of the market, most farmers already know the price of organic fertilizers in agricultural kiosks, significantly subsidized fertilizers. Farmers in Karangtengah Prandon Village use subsidized organic fertilizer from PT Petrokimia. Market competition for organic fertilizer products is also less so it is potential for developing organic fertilizer from beef cattle manure.

The market has five criteria: market availability, the level of fertilizer demand within the village, the level of fertilizer demand outside the village, market competition, and fertilizer 4 Hijami et al. prices. In this availability criteria, 1 criteria are less potential, namely the price of organic fertilizer. Farmers assume that the organic fertilizer can be said to be cheap for Rp. 32,000. The fertilizer is subsidized fertilizer from the government. In addition to the criteria for the price of organic fertilizer, four other criteria are declared potential. Some farmers establish good communication with extension workers. This condition causes farmers to get information on fertilizer needs inside and outside the village. On the criteria of market competition, there are no competitors for organic fertilizer products other than official agricultural shops. The development of this potential can be said to be potential.

\subsection{Social Aspect}

Table 4. Social Aspects Potential of Organic Fertilizer Business Development from Beef Cattle Manure in Karangtengah Prandon Village

\begin{tabular}{|c|c|c|c|}
\hline No & Social Aspects Potential & Category & $\begin{array}{c}\text { Percentage } \\
(\%)\end{array}$ \\
\hline \multirow[t]{4}{*}{1} & Labor Conditions & Less Potential & 43.7 \\
\hline & a. Labor Availability & Less Potential & 38.5 \\
\hline & b. Training Intensity & Less Potential & 56 \\
\hline & c. Labor Skills & Less Potential & 36.5 \\
\hline \multirow[t]{4}{*}{2} & Human Resources Quality & Less Potential & 49 \\
\hline & $\begin{array}{l}\text { a. Knowledge of Fertilizer } \\
\text { manufacture }\end{array}$ & Less Potential & 50 \\
\hline & $\begin{array}{l}\text { b. Knowledge of Fertilizer } \\
\text { Making Process }\end{array}$ & Less Potential & 42.5 \\
\hline & $\begin{array}{l}\text { c. Knowledge of Fertilizer } \\
\text { Making Time }\end{array}$ & Less Potential & 51.3 \\
\hline \multirow[t]{3}{*}{3} & Community Leader Support & Less Potential & 54 \\
\hline & a. Community Support & Less Potential & 58.7 \\
\hline & $\begin{array}{l}\text { b. Assistance (Moral and } \\
\text { Material) }\end{array}$ & Less Potential & 49.3 \\
\hline
\end{tabular}

The social aspect is divided into three potential aspects: the condition of the workforce, the quality of human resources, and the support of community leaders. The study results from the social aspect are classified as less potential with a percentage of $47.9 \%$. The three potential social aspects are classified in the category of less potential.

In terms of labor conditions, most farmers stated that there was a lack of labor and no skills in utilizing cow manure into organic fertilizer. This phenomenon is due to the lack of intensity of extension carried out by field workers in the three farmer groups studied. The majority of farmers in the study have never received counseling on cow manure in organic fertilizer.

In addition, labor conditions are divided into three criteria: the availability of labor, training intensity, and labor skills. The results of the study of the three criteria are categorized as less potential. The labor criteria are categorized as less potential because of the lack of workers needed in organic fertilizer business activities. This shortage of human resources is caused by many residents migrating to look for more decent jobs than work in the village.

The criteria for training intensity are categorized as less potential because the farmers in this study have never received education or counseling from field officers. In addition, the labor 
skills are categorized as less potential because there is no counseling on the subject of this study. Several farmers who were met during the research stated that the cow manure used in the fields was cow manure that was left for 1-2 months without being given additional substances or fermentation.

On the potential aspects of the quality of human resources, most farmers' knowledge is still minimal about how to use cow manure in organic fertilizer. The majority of farmers stated that the procedure for making organic fertilizer is only by letting it sit for a few weeks without composting or fermenting cow manure. This procedure invites pests, diseases, and weeds to the cultivated plants. Because of this situation, it is necessary to empower and educate farmers about making organic fertilizer from cow manure.

The quality of human resources is divided into 3 criteria: knowledge of fertilizer manufacture, fertilizer making process, and fertilizer making time. Based on the study results, all criteria on the potential aspects of the quality of human resources are categorized as less potential. This condition is because the farmers in this study do not yet know the proper and proper use of cow manure. There is no education/counseling on the potential utilization of cow manure into organic fertilizer.

The support of community leaders can be in the form of moral assistance in the form of positive responses and moral assistance in material assistance and others. In this study, most farmers stated that there was assistance from community leaders in the form of moral assistance such as attention and motivation from several community leaders such as the chairman of the farmer group association, village head, and others. However, for moral assistance, the farmers stated that there was no assistance from community leaders for several reasons, such as there are still many priorities from community leaders who deserve moral support.

In terms of the potential aspects of the support of community leaders, it is divided into two criteria, namely community support and assistance (moral and material). Both criteria are categorized as less potential. These two criteria are declared to be less potential because organic fertilizer business activities have not yet started and the farmers' capital limitations in Karangtengah Prandon Village. The support of community leaders can motivate farmers who want to do organic fertilizer business from cow manure waste.

\section{CONCLUSION}

Based on a study on the Analysis of Potential Development of Organic Fertilizer Business from Beef Cattle Manure in Karangtengah Prandon Village, Ngawi Sub District, Ngawi Regency, which has been analyzed, the following conclusions can be drawn: (a) The availability of technical aspects is in the potential category with a percentage of $64.4 \%$ in developing organic fertilizer business from beef cattle manure in Karangtengah Prandon Village. However, several criteria have less potential, namely the place of organic fertilizer production, tools and materials, availability of facilities and infrastructure, and equipment preparation; (b) The availability of economic aspects is in the potential category with a percentage of $62.7 \%$ in the development of organic fertilizer business from beef cattle manure in Karangtengah Prandon Village. However, some criteria have less potential, namely the availability of capital, the https://doi.org/10.29165/ajarcde.v6i1.80 ease of obtaining capital, and the fertilizer price; (c) The availability of social aspects is in the category of less potential with $47.9 \%$ in the development of organic fertilizer business from beef cattle manure in Karangtengah Prandon Village.

\section{ACKNOWLEDGEMENT}

The authors gratefully acknowledged the Polytechnic of Agricultural Development Yogyakarta-Magelang for the facilities that have been used during the implementation of research activities.

\section{REFERENCES}

[1] S. W. Prasetyaningtyas, S. Maaruf, R. Sobir, and A. Hermawan, "Using interpretive structure modelling in developing an organic farming sustainability strategy in Indonesia," J. Agric. Ext., vol. 23, no. 3, pp. 196-207, 2019, doi: 10.4314/jae.v23i3.17.

[2] V. Schreer and M. Padmanabhan, "The many meanings of organic farming: framing food security and food sovereignty in Indonesia," Org. Agric., vol. 10, no. 3, pp. 327-338, 2020, doi: 10.1007/s13165-019-00277-z.

[3] T. T. Nguyen, Y. Sasaki, M. Katahira, and D. Singh, "Cow manure application cuts chemical phosphorus fertilizer need in silage rice in Japan," Agronomy, vol. 11, no. 8, pp. 1-12, 2021, doi: 10.3390/agronomy 11081483 .

[4] Anonim, "Kabupaten Ngawi Dalam Angka." Indonesian Statistics Center, 2020.

[5] Anonim, "Programa Desa Karang Tengah Prandon." 2021.

[6] T. Dalorima, S. Z. Sakimin, and R. M. Shah, "Utilization of organic fertilisers a potential approaches for agronomic crops: A review," Plant Sci. Today, vol. 8, no. 1, pp. 190-196, 2021, doi: 10.14719/pst.2021.8.1.1045.

[7] S. Ginting, "Promoting Bokashi as an Organic Fertilizer in Indonesia: A Mini Review," Int. J. Environ. Sci. Nat. Resour., vol. 21, no. 4, pp. 142-144, 2019, doi: 10.19080/ijesnr.2019.21.556070.

[8] A. Zulkarnaini and A. Yuniar Saleh, "Analisis Kelayakan Pembangunan Usaha Pupuk Organik di Provinsi Lampung," J. Online Inst. Teknol. Nas., vol. 01, no. 03, pp. 243-253, 2014.

[9] Y. Ramli and U. M. Buana, "Implementing Competitive Strategy : to develop the resources of Organic Fertilizer Industries in Indonesia and to enhance the Business Performance," vol. 22, no. 1, pp. 63-73, 2020, doi: 10.9790/487X-2201076373.

[10] Anonim, Pedoman Teknis Pengembangan Unit Pengolah Pupuk Organik (Technical Guidelines for the Development of Organic Fertilizer Processing Units). Directorate of Fertilizer and Pesticide, Ministry of Agriculture, Indonesia, 2014.

[11] P. K. Igbokwe, C. O. Asadu, and E. C. Okpe, "Manufacture of Bio Fertilizer by Composting Sawdust and Other Organic Waste," Int. J. Nov. Res. Phys. Chem. Math., vol. 2, no. 3, pp. 6-15, 2015.

[12] A. Nasution and C. Yoman, "Feasibility Analysis and Strategy for Fertilizer," vol. 5, no. 1, pp. 72-81, 2021. 